\title{
Two New Species of Doridicola (Copepoda: Cyclopoida: Rhynchomolgidae) Associated with Opisthobranch Mollusks from Korea
}

\author{
Il-Hoi Kim* \\ Department of Biology, Kangnung National University, Gangneung 210-702, Korea
}

\begin{abstract}
Two new species of the genus Doridicola are described as associates of opisthobranch mollusks from Korean intertidal waters: Doridicola virguatus n. sp. associated with the notaspidean Pleurobranchaea japonica Thiele and $D$. portincola $n$. sp. associated with the nudibranch Hoplodoris armata (Baba). This is the first record for the copepod associates of opisthobranch mollusks from Korea.
\end{abstract}

Key words: Doridicola, new species, Rhynchomolgidae, Copepoda, Opisthobranchia, association, Korea

\section{INTRODUCTION}

Doridicola Leydig, 1853 is the largest genus of the family Rhynchomolgidae. Copepods of this genus are associated with various marine invertebrates, such as Porifera, Cnidaria, Mollusca, and Echinodermata (Humes and Boxshall, 1996; Boxshall and Halsey, 2004). Ho and Kim (2001) recognized 45 species as valid in the genus Doridicola. Two species, $D$. parvicaudatus and $D$. parapatulus have since been added in this genus by $\operatorname{Kim}(2003)$ and $\operatorname{Kim}$ (2004), respectively. Among a total of 47 known species of Doridicola, eight are known to be associated with opisthobranchs (order Nudibranchia): D. agilis Leydig, 1853 from Europe; D. gracilipes (A. Scott, 1909) from Timor; D. parapatulus Kim, 2004 from Australia; and D. commodus (Humes, 1964), D. patulus (Humes, 1959), D. securiger (Humes, 1964), D. sensilis (Humes, 1964), and D. venustus (Humes, 1959), all five from Madagascar.

From Korea only a single species, D. sepiae (Izawa, 1976), has been reported by Kim (1998) as associate of a cuttlefish (Cephalopoda). In the present paper two new species of the genus are described as associates of opisthobranch mollusks, one from the Notaspidea and the other from the Nudibranchia.

Family Rhynchomolgidae Humes and Stock, 1972

Genus Doridicola Leydig, 1853

${ }^{1} *$ Doridicola virgatus n. sp. (Figs. 1-3)

\footnotetext{
*To whom correspondence should be addressed

Tel: 82-33-640-2312, Fax: 82-33-642-6124
}

E-mail: ihkim@kangnung.ac.kr
Material examined. Thirty 우 우 and $32 \sigma^{\pi} \sigma^{\pi}$ collected from 60 individuals of the notaspidean Pleurobranchaea japonica Thiele at tidal pools near Gosapo Beach $\left(35^{\circ} 44^{\prime} 42^{\prime \prime} \mathrm{N}, 126^{\circ}\right.$ $\left.30^{\prime} 43^{\prime \prime} \mathrm{E}\right)$, Buan, in the Yellow Sea, intertidal, on 14 May 2003. Holotype (우), allotype, and paratypes (20우 우, 20 주 ð) will be deposited in the National Biological Resource Institute, Korea. Dissected paratypes (2우 우, $2 \sigma^{\Im}$ ) and other specimens are kept in the collection of the author.

Female. Body (Fig. 1A) dorsoventrally flat and moderately narrow. Length $1.65 \mathrm{~mm}(1.48-1.27 \mathrm{~mm}$, mean $1.59 \mathrm{~mm})$, excluding caudal setae, based on 10 specimens. Greatest width $624 \mu \mathrm{m}$. Length of prosome $1.03 \mathrm{~mm}$. First pedigerous somite separated from cephalosome by faint dorsal furrow. Rostral area roundly produced anteriorly. Urosome (Fig. 1B) 5-segmented. Fifth pedigerous somite $190 \mu \mathrm{m}$ wide, laterally projected, with small, smooth dorsolateral seta on each side. Genital double-somite $220 \mu \mathrm{m}$ long, consisting of broad, roundly expanded anterior part (199 $\mu \mathrm{m}$ wide across this area) and short, narrower posterior part (136 $\mu \mathrm{m}$ across this area). Three abdominal somites unornamented, $88 \times 120,75 \times 101$, and $60 \times 107 \mu \mathrm{m}$, respectively, from anterior to posterior. Anal somite with pair of sensilla on middle of dorsal surface. Caudal rami widely separated from each other. Each ramus (Fig. 1D) $75 \times 38 \mu \mathrm{m}$, ratio $1.97: 1$, with slightly convex inner margin and 6 caudal setae; outer lateral seta smooth, located slightly posterior to middle of lateral margin; dorsal seta small, smooth, and located near inner distal corner; outermost and innermost ones of terminal setae plumose only along inner side; two median terminal setae weakly plumose.

Egg sac variable in size, largest one $825 \times 350 \mu \mathrm{m}$, slightly tapering, containing numerous eggs; each egg about 50

1*올빼미군소붙이살이 (신칭) 


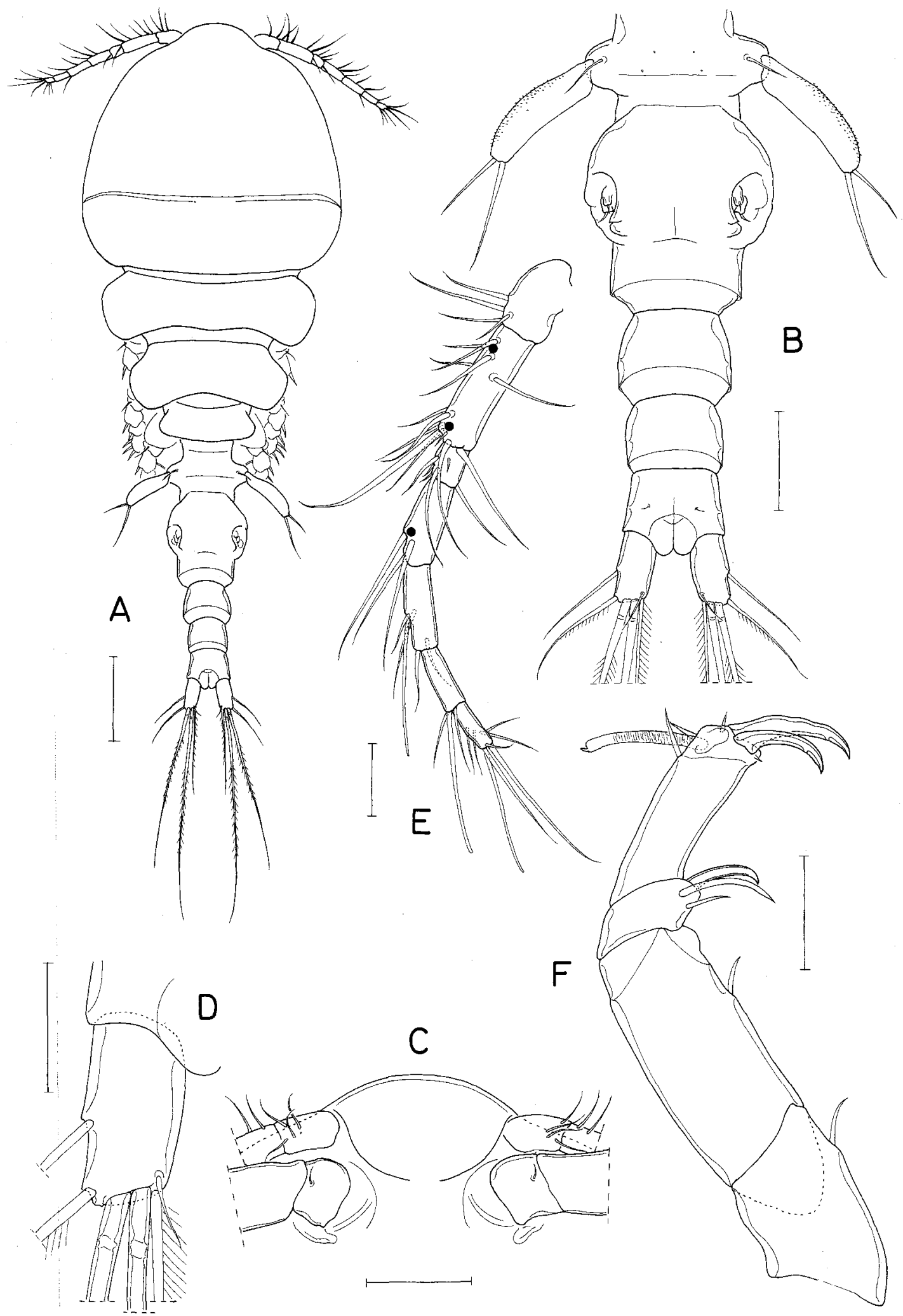

Fig. 1. Doridicola virgatus n. sp., female. A, habitus, dorsal; $B$, urosome, dorsal; $C$, rostral area, ventral; $D$, caudal ramus, dorsal; $E$, antennule (dark spots indicate insertions of additional aesthetascs in male); $F$, antenna. Scale bars $=0.2 \mathrm{~mm}(A), 0.1 \mathrm{~mm}(B, C)$, $0.05 \mathrm{~mm}(\mathrm{D}-\mathrm{F})$. 

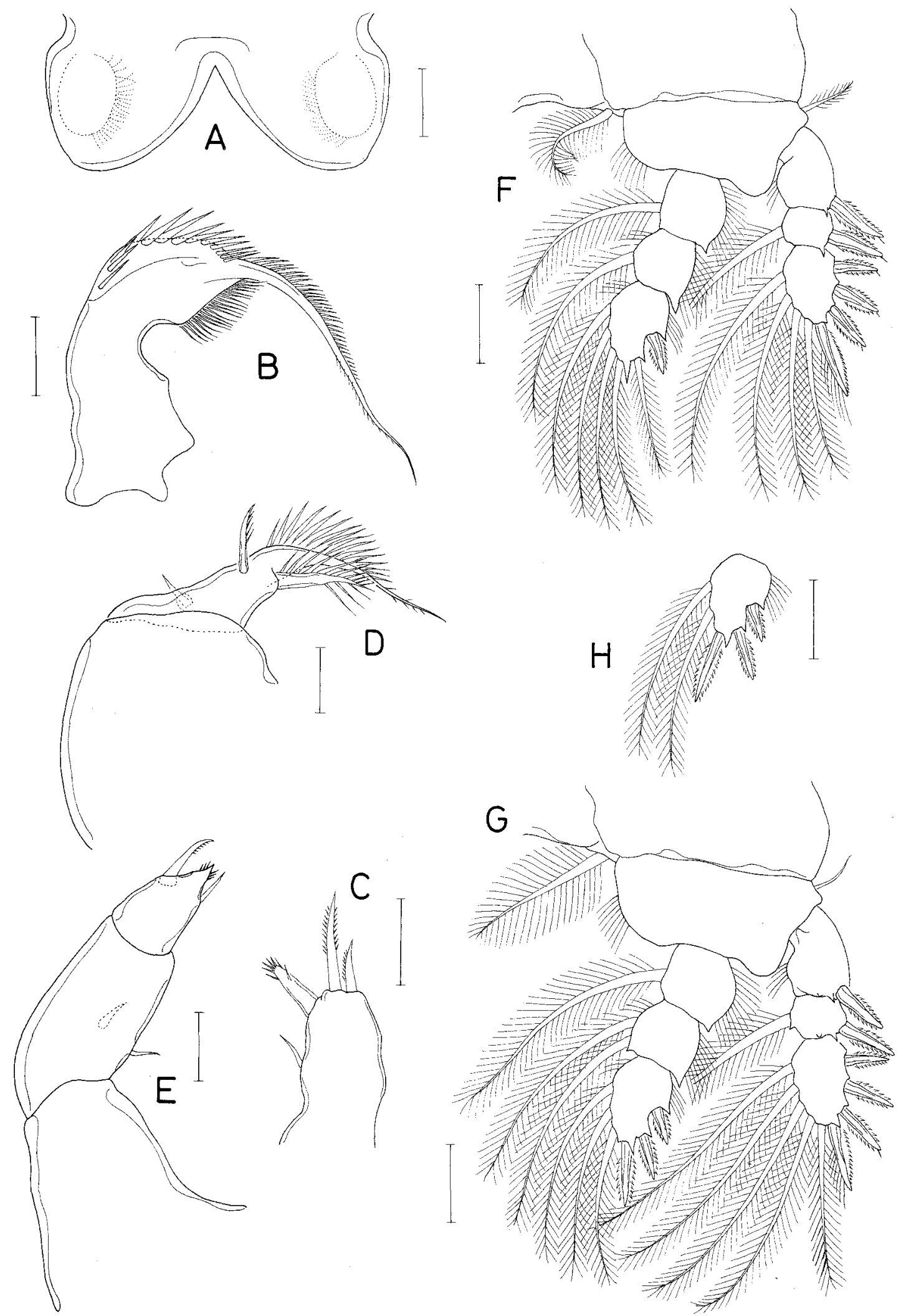

Fig. 2. Doridicola virgatus $n$. sp., female. $A$, labrum; $B$, mandible; $C$, maxillule; $D$, maxilla; $E$, maxilliped; $F$, leg $1 ; G$, leg $2 ; H$, third endopodal segment of leg 3 . Scale bars $=0.02 \mathrm{~mm}(A-E), 0.05 \mathrm{~mm}(F-H)$. 


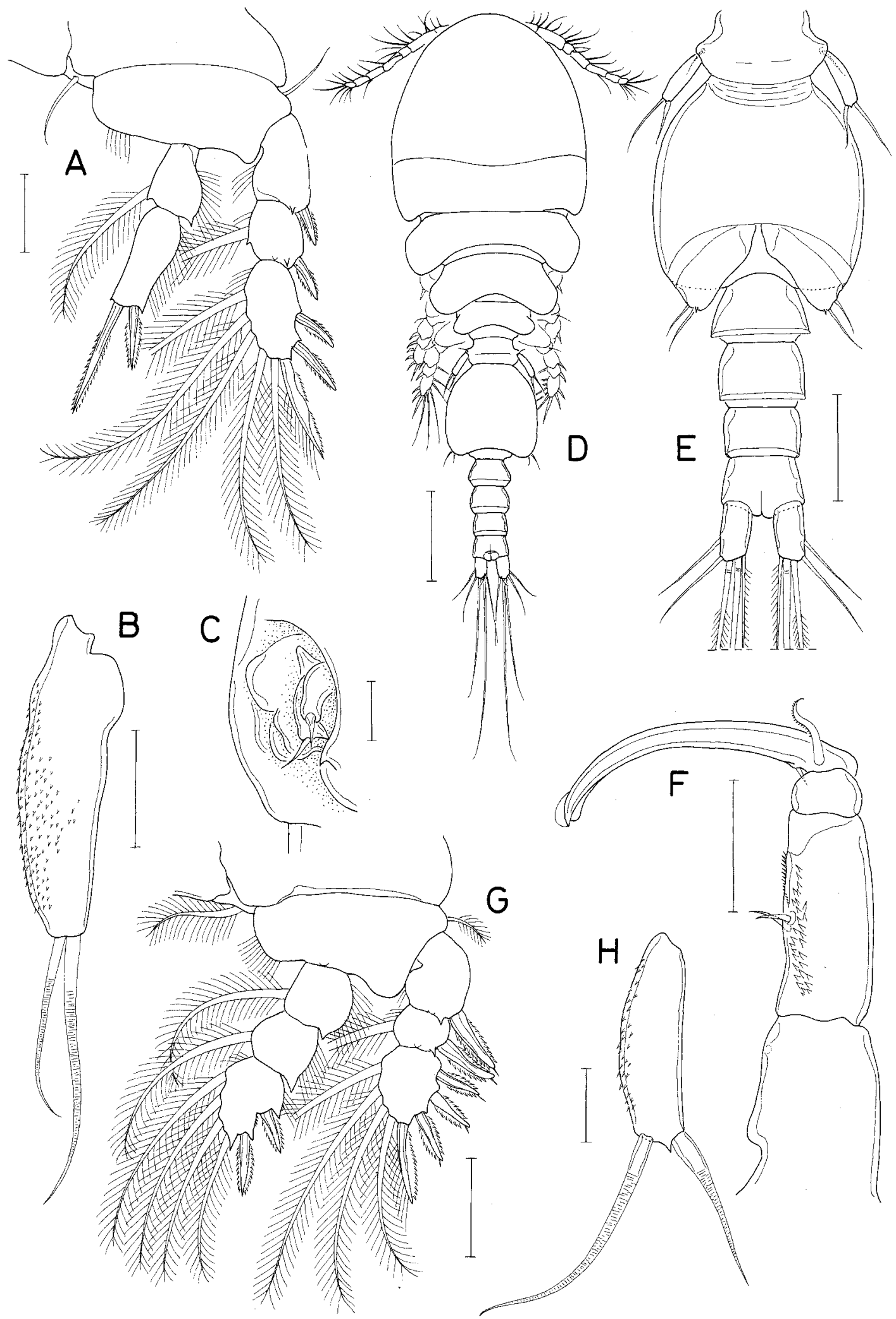

Fig. 3. Doridicola virgatus $\mathrm{n}$. sp. Female: $A$, leg 4; $B$, free segment of leg 5 ; $C$, genital area. Male: $D$, habitus, dorsal; $E$, urosome, ventral; $F$, maxilliped; $G$, leg $1 ; H$, free segment of leg 5 . Scale bars $=0.05 \mathrm{~mm}(A, B, F, G), 0.02 \mathrm{~mm}(C, H), 0.2 \mathrm{~mm}(D), 0.1 \mathrm{~mm}$ (E). 
$\mu \mathrm{m}$ in diameter.

Rostrum broad, its rounded posterior margin almost fused with body surface (Fig. 1C). Antennule (Fig. 1E) 7-segmented, and $366 \mu \mathrm{m}$ long; its armature formula 4, 13, 6, 3, $4+$ aesthetasc, $2+$ aesthetasc, and $7+$ aesthetasc; all seta smooth. Antenna (Fig. 1F) 4-segmented. First 2 segments robust, each armed with 1 inner seta. Small third segment armed with 1 claw and 2 setae. Fourth segment approximately $75 \times 28 \mu \mathrm{m}$, armed with 2 claws and 5 setae; one of outer distal setae enlarged, rod-shaped and tipped by small process.

Labrum (Fig. 2A) posteriorly bilobed, with broad median incision. Mandible (Fig. 2B) with broad proximal notch; inner margin straight, perpendicular to base of lash; convex margin distally with spines; lash long, whip-like. Paragnath lobate, with setules on inner side (Fig. 2A). Maxillule (Fig. 2C) with 1 lateral and 3 spinulated distal setae, one of latters blunt and tipped by several spinules. Maxilla (Fig. 2D) 2segmented; first segment unarmed; second segment with small outer setule (seta III) at base, spiniform, setule-bearing seta (seta II) on anterior surface, and larger seta (seta I) bearing long spinules on margins; terminal lash with large spinules on convex side. Maxilliped (Fig. 2E) 3-segmented; first segment unarmed; second segment with 2 small, similar setae; third segment terminating in barbed spiniform process, with 1 spiniform seta and 1 smaller, simple seta at base.

Legs 1-4 with 3-segmented rami, except for 2-segmented endopod of leg 4. Armature formula of legs 1-4 as follows:

Leg 1: coxa 0-1; basis 1-0; exp. I- 0 ; I-1; III,I,4; enp. $0-1 ; 0-1 ; 1,5$

Leg 2: coxa 0-1; basis 1-0; exp. I-0; I-1; III,I,5; enp. $0-1 ; 0-1 ;$ III,3

Leg 3: coxa 0-1; basis 1-0; exp. I-0; I-1; III,I,5; enp. $0-1 ; 0-1 ;$ III, 2

Leg 4: coxa 0-1; basis 1-0; exp. I-0; I-1; II,I,5; enp. $0-1 ;$ II

Outer seta on basis of legs 2-4 smooth and small. Leg 4 (Fig. 3A) with smooth inner coxal seta; second endopodal segment $67 \times 29 \mu \mathrm{m}$, its 2 terminal spines $77 \mu \mathrm{m}$ (inner) and $40 \mu \mathrm{m}$ (outer).

Leg 5 with free segment (Fig. 3B) $139 \times 41 \mu \mathrm{m}$, ratio 3.39 $: 1$, bearing weak inner proximal expansion, numerous spinules on outer surface, and 2 terminal setae of $115 \mu \mathrm{m}$ (inner) and $82 \mu \mathrm{m}$ (outer). Leg 6 represented by 2 setae in genital area (Fig. 3C).

Male. Body (Fig. 3D) similar to that of female. Length 1.26 $\mathrm{mm}(1.21-1.35 \mathrm{~mm})$, based on 10 specimens. Greatest width $435 \mu \mathrm{m}$. Rostral area not differentiated in dorsal view of body. Urosome (Fig. 3E) 6-segmented. Fifth pedigerous somite narrow, $128 \mu \mathrm{m}$ wide. Genital somite $222 \mu \mathrm{m}$ long (measured from anterior border to tip of genital flap) or 175 $\mu \mathrm{m}$ long (measured through midline), and $200 \mu \mathrm{m}$ wide. Four abdominal somites $55 \times 95,60 \times 82,48 \times 75$ and $45 \times$ $80 \mu \mathrm{m}$, respectively. Caudal ramus $57 \times 29 \mu \mathrm{m}$, ratio 1.92 : 1 , as in female.

Rostrum as in female. Antennule added by 3 aesthetascs at opposite side of locations indicated by dots in Fig. 1E. Antenna added by small spinules on inner margin of first and second segments.

Labrum, mandible, maxillule, and maxilla as in female. Maxilliped (Fig. 3F) 3-segmented; first segment unarmed; second segment with 2 similar inner setae, spinules and row of munite spinules on inner side; small third segment unarmed; terminal claw distinctly shorter than proximal 3 segments combined, with 2 very unequal setae proximally.

Leg 1 (Fig. 3G) with third endopodal segment armed with 2 spines and 4 setae (formula I,I,4). Terminal process on third endopodal segment of legs 2 and 3 more acute and prominent than in female

Free segment of leg 5 (Fig. $3 \mathrm{H}$ ) $57 \times 17 \mu \mathrm{m}$, ratio $3.35: 1$, terminally with 1 pointed process and 2 setae $(70 \mu \mathrm{m}$ and 46 $\mu \mathrm{m}$, respectively), smaller inner one of them proximally expanded. Leg 6 represented 2 smooth setae and 1 pointed process on genital flap (Fig. 3E).

Etymology. The specific name virgatus is a Latin meaning "made of a rod", alluding to the possession of a rod-shaped seta on the terminal segment of antenna.

Remarks. A characteristic seta on the terminal segment of the antenna, which is transformed to a blunt, enlarged element tipped by a nipple-shaped process, renders the new species Doridicola virgatus differentiate from all congeners.

Doridicola virgatus $\mathrm{n}$. sp. can be distinguished from its congeners by other ways. As a diagnostic character, it has a claw, in addition to a pair of setae, on the third segment of the antenna. According to Ho and Kim (2001), this characters is shared by 10 known species in Doridicola. Of these, only two species, D. longicauda (Claus, 1860) and D. aculeatus (Humes and Ho, 1968), has the caudal rami bearing a range of the ratio of the length to width, $1.59-2.50: 1$, as the new species (1.97:1).

Doridicola longicauda is a species associated with the cephalopod Sepia officinalis Linnaeus in Europe. According to Ho (1983), in D. longicauda the caudal ramus is 2.2 times as long as wide, the free segment of female leg 5 is smooth without spinules or denticles, and the genital double-somite of the female bears a peculiar dorsal bulge which is characteristic to the species of Doridicola associated with cephalopods. These features are not adjustable to $D$. virgatus $n$. sp., because in the latter species the caudal ramus is 1.97 times as long as wide in both sexes, the free segment bears a number of denticles, and the genital double-somite does not bear 
dorsal buldge.

Unlike in the new species, in D. aculeatus the two terminal claws of the antenna is elongate, longer than terminal segment, with its first and second segments bearing spinules on inner margin, the distal segment of leg 4 is elongate and its two terminal spines are extremely unequal, inner one is more than 3 times as long as outer one (Humes and Dojiri, 1979), the inner margin of the mandible is perpendicular to terminal lash, and the free segment of male leg 5 bears one spine and one seta (Humes and Ho, 1968).

\section{${ }^{1} *$ Doridicola portincola n. sp. (Figs. 4-6)}

Material examined. Five 우우 and $5 \sigma^{7} \sigma^{7}$ collected from one pair of the nudibranch Hoplodoris armata (Baba) at rocky intertidal shore in Seogwipo port $\left(33^{\circ} 14^{\prime} 14^{\prime \prime} \mathrm{N}, 126^{\circ}\right.$ $33^{\prime} 39^{\prime \prime} \mathrm{E}$ ) in Jeju Island, on 30 March 2006. Holotype (우), allotype, and paratypes ( 3 우 우, $3 \sigma^{\pi} \sigma^{7}$ ) will be deposited in the National Biological Resource Institute, Korea. Dissected paratypes $\left(1\right.$ 우 $\left.1 \sigma^{7}\right)$ are kept in the collection of the author. Female. Body (Fig. 4A) $1.42 \mathrm{~mm}$ long, with moderately broad prosome and small urosome. Cephalothorax $647 \times$ $712 \mu \mathrm{m}$, nearly circular, with slightly pronounced rostral area and faint dorsal transverse furrow delimiting cephalosome and first pedigerous somite. Urosome (Fig. 4B) 5-segmented. Fifth pedigerous somite $194 \mu \mathrm{m}$ wide. Genital double-somite $179 \times 200 \mu \mathrm{m}$ (ratio $0.90: 1$ ), consisting of wide anterior part and short, narrower posterior part. Three free abdominal somites $46 \times 107,38 \times 104$, and $60 \times 104 \mu \mathrm{m}$, respectively. Caudal ramus (Fig. 4 C) $37 \times 39 \mu \mathrm{m}$ (ratio 0.95 : 1), bearing fine spinules on posteroventral margin and 6 setae; largest terminal seta $647 \mu \mathrm{m}$ long; innermost terminal seta plumose along inner margin, other 5 setae naked. Egg sac unknown.

Rostrum (Fig. 4D) broad, with rounded posterior margin. Antennule (Fig. 4E) 7-segmented and $401 \mu \mathrm{m}$ long, with armature formula 4, 13, 6, 3, 4+aesthetasc, 2+aesthetasc, and 7 +aesthetasc; all setae naked. Antenna (Fig. 4F) 4-segmented, with armature formula 1, 1,2+claw, and 5+2 claws; two claws on terminal segment unequal, both distinctly shorter than terminal segment, 59 and $35 \mu \mathrm{m}$, respectively.

Labrum (Fig. 4G) much wider than long, with broad median incision. Mandible (Fig. 4H) with distinct proximal notch, followed by row of small spinules along long, straight inner margin; convex margin with spinulated, lobate area followed by long, spinulated terminal lash. Maxillule (Fig. 4I) armed with 1 lateral setiform process and 3 terminal setae, one of latters broader than other 2. Maxilla (Fig. 5A) 2-segmented; first segment unarmed; second segment with small outer setule (seta III) at base, spiniform, setule-bearing seta (seta II) on anterior surface, and larger seta (seta I) with long spinules on margins; terminal lash elongated, proximally with 2 rows of spinules (row of large spinules and another, subsidiary row of small spinules) on convex margin.

Maxilliped (Fig. 5B) 3-segmented; first segment unarmed. Second segment with 2 extremely unequal setae, each 46 and $13 \mu \mathrm{m}$ long; third segment terminating in barbed, spiniform process, with 1 barbed spine and 1 small seta at base.

Legs 1-4 with 3-segmented rami, except for 2-segmented endopod of leg 4. Armature formula of legs $1-4$ as follows:

Leg 1: coxa 0-1; basis 1-0; exp. I-0; I-1; III,I,4; enp. $0-1 ; 0-1 ; \mathrm{I}, 5$

Leg 2: coxa 0-1; basis 1-0; exp. I-0; I-1; III,I,5; enp. $0-1 ; 0-1 ;$ III,3

Leg 3: coxa 0-1; basis 1-0; exp. I-0; I-1; III,I,5; enp. $0-1 ; 0-1 ;$ III, 2

Leg 4: coxa 0-1; basis 1-0; exp. I-0; I-1; II,I,5; enp. $0-1 ;$ II

Leg 4 (Fig. 5F) with minute, naked inner coxal seta; second endopodal segment $67 \times 27 \mu \mathrm{m}$, its 2 terminal spines 43 $\mu \mathrm{m}$ (inner) and $33 \mu \mathrm{m}$ (outer).

Leg 5 with slender free segment (Fig. 5G) $81 \times 19 \mu \mathrm{m}$ (ratio $4.26: 1$ ), $15 \mu \mathrm{m}$ wide in narrower distal part, bearing prominent inner proximal expansion, minute spinules on distal half of outer surface, and 2 terminal setae of $104 \mu \mathrm{m}$ (inner) and $77 \mu \mathrm{m}$ (outer). Leg 6 represented by 2 setae in genital area (Fig. 4B).

Male. Body (Fig. 6A) similar in form to that of female. Length $1.07 \mathrm{~mm}$ in dissected specimen. Rostral area not prominent. Urosome (Fig. 6B) 6-segmented. Fifth pedigerous somite small, $117 \mu \mathrm{m}$ wide. Genital somite $192 \times 223 \mu \mathrm{m}$. Four abdominal somites $38 \times 71,36 \times 67,25 \times 63$, and $31 \times$ $69 \mu \mathrm{m}$, respectively. Caudal ramus $25 \times 26 \mu \mathrm{m}$ (ratio 0.96 : $1)$.

Rostrum as in female. Antennule added by 3 aesthetascs at opposite side of locations indicated by dots in Fig. 4E. Antenna added by small spinules on inner margin of second segment; inner seta on first and second segments slightly expanded proximally and bearing spinlules on inner side (Fig. 6C).

Labrum, mandible, maxillule, and maxilla as in female. Maxilliped (Fig. 6D) 3-segmented; first segment unarmed; second segment with 2 small setae and 1 inner row of munite spinules; small third segment unarmed; terminal claw distinctly shorter than proximal 3 segments combined, with 2 very unequal setae proximally.

Leg 1 with third endopodal segment armed with 2 spines

1 *갑옷갯민숭달팽이살이 (신칭) 


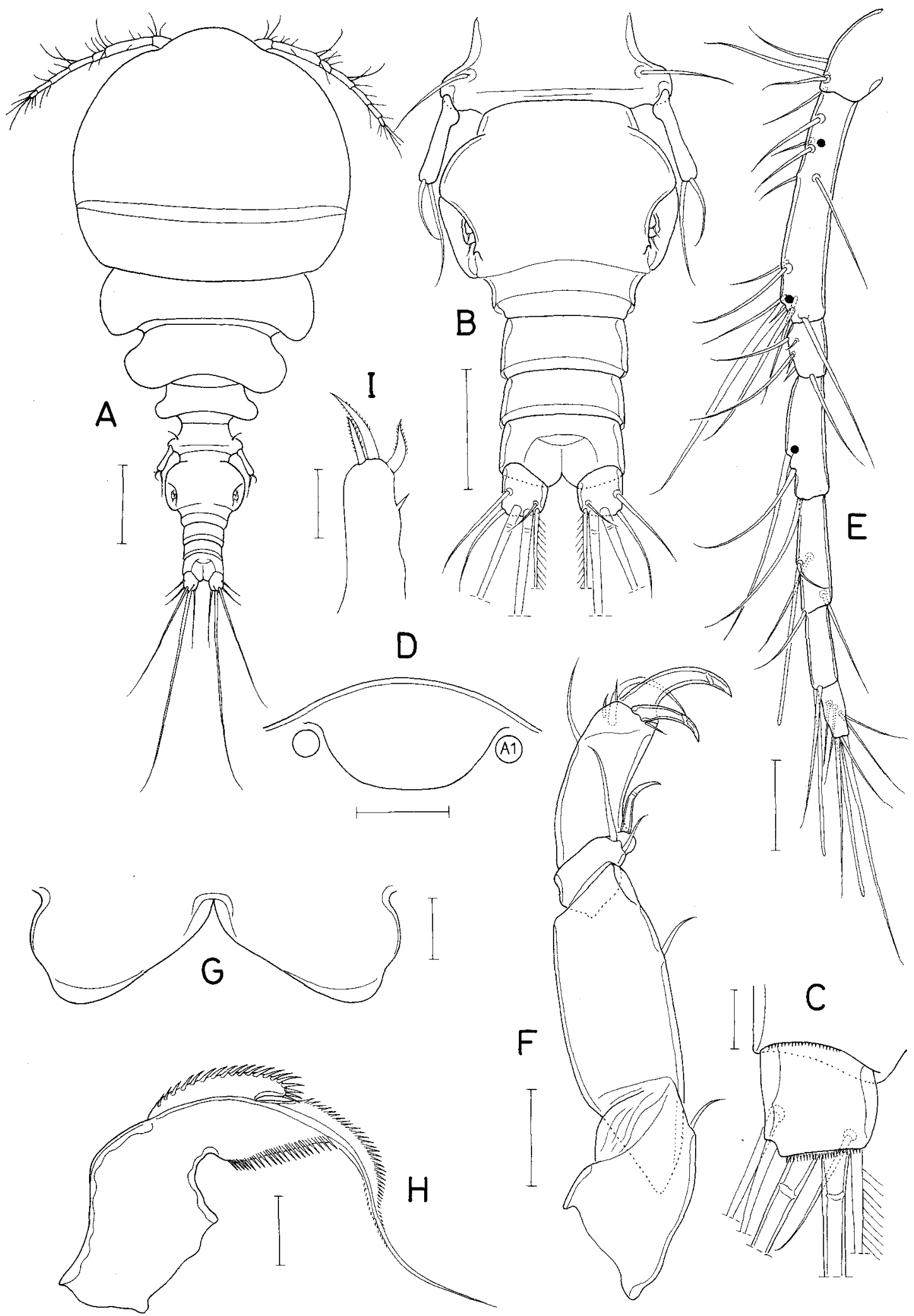

Fig. 4. Doridicola portincola n. sp., female. A, habitus, dorsal; $B$, urosome, dorsal; $C$, right caudal ramus, ventral; $D$, rostral area, ventral; $E$, antennule (dark spots indicate insertions of additional aesthetascs in male); $F$, antenna; $G$, labrum; $H$, mandible; $I$, maxillule. Scale bars $=0.2 \mathrm{~mm}(A), 0.1 \mathrm{~mm}(B, D), 0.02 \mathrm{~mm}(C, G-I), 0.05 \mathrm{~mm}(E, F)$. 

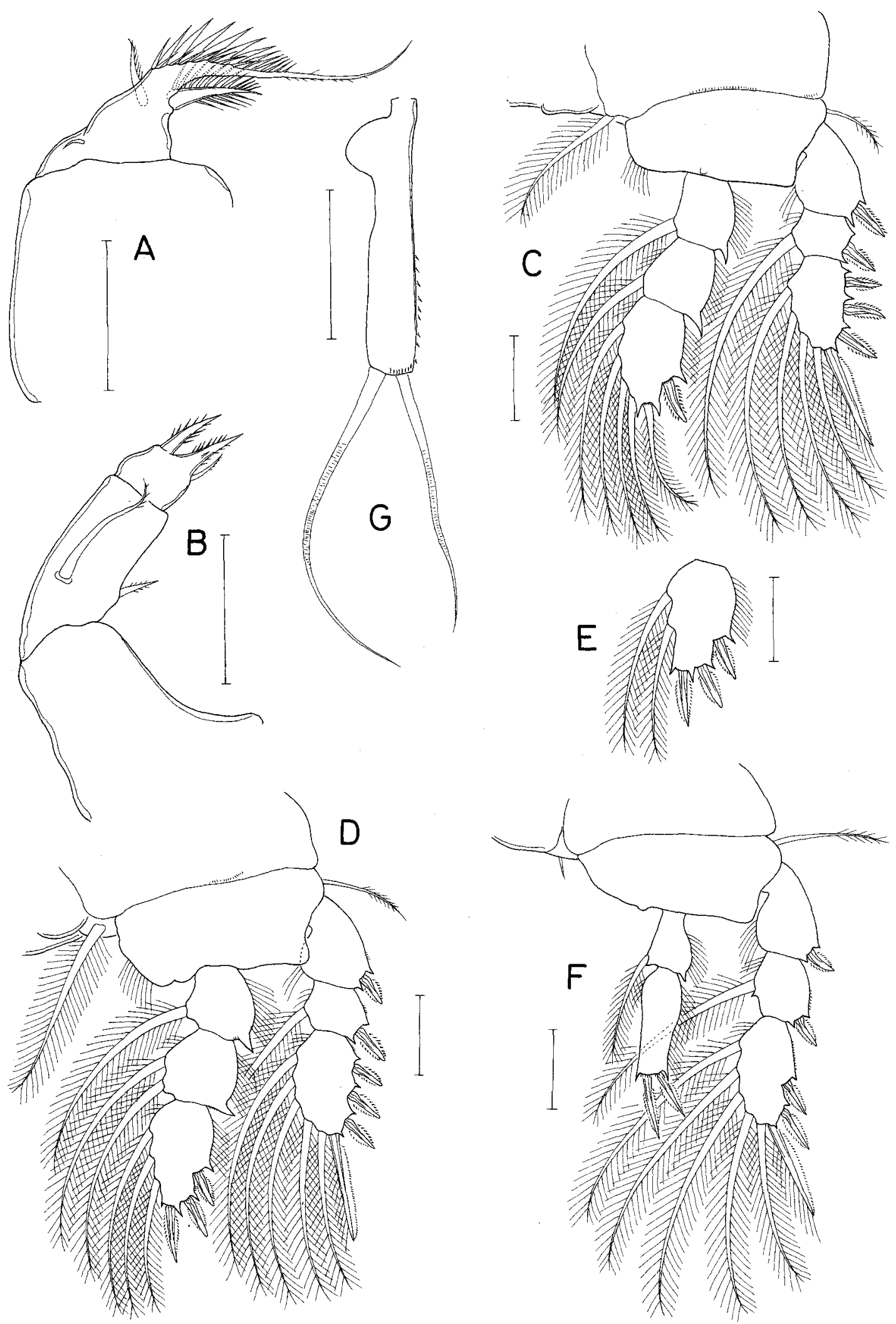

Fig. 5. Doridicola portincola n. sp., female. A, maxilla; B, maxilliped; C, leg 1 ; $D$, leg $2 ; E$, third endopodal segment of leg 3; $F$, leg $4 ; G$, free segment of leg 5 . Scale bars $=0.05 \mathrm{~mm}(A-G)$. 


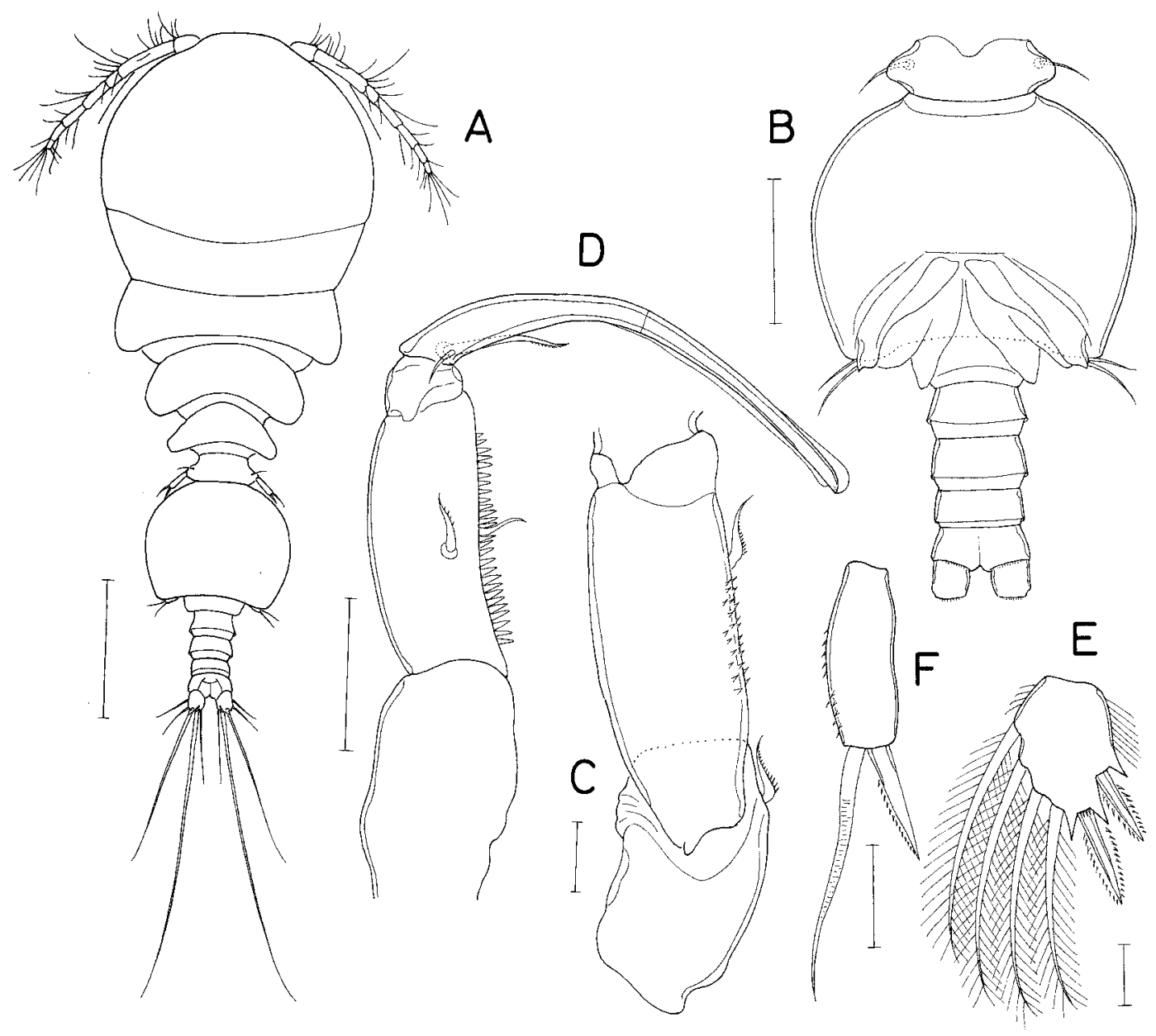

Fig. 6. Doridicola portincola n. sp., male. A, habitus, dorsal; $B$, urosome, ventral; $C$, proximal part of antenna; $D$, maxilliped; $E$, third endopodal segment of leg $1 ; F$, free segment of leg 5 . Scale bars $=0.2 \mathrm{~mm}(A), 0.1 \mathrm{~mm}(B), 0.02 \mathrm{~mm}(C, E, F), 0.05 \mathrm{~mm}(D)$.

and 4 setae (formula I,I,4) (Fig. 6E). Legs $2-4$ as in female.

Free segment of leg 5 (Fig. $6 \mathrm{~F}$ ) $37 \times 13 \mu \mathrm{m}$, ratio $2.85: 1$, terminally armed with 1 spine $(23 \mu \mathrm{m})$ bearing minute spinules along medial margin and 1 naked seta $(50 \mu \mathrm{m})$. Leg 6 represented by 2 smooth setae on genital flap (Fig. 6B).

Etymology. The specific name portincola is a combination of the Latin words portus (=port) and incola (=-dwelling), which alludes to the discovery of the new species in a port.

Remarks. According to Ho and $\operatorname{Kim}$ (2001), nine known species of Doridicola have very unequal setae on the second segment of female maxilliped (one of two setae is more than twice as long as the other). They are D. claudus (Humes and Stock, 1973); D. connexus Humes, 1986; D. gracilipes (A. Scott, 1909); D. inaequalis (Humes and Ho, 1966); D. micropus (Humes, 1973); D. myorae (Greenwood, 1971); D. patulus (Humes, 1959); D. sensilis (Humes, 1964); D. venustus (Humes, 1959). In addtion, D. parapatulus Kim, 2004 which has been recorded later than Ho and Kim (2001) has the same morphology in the maxilliped as in those nine species. However, only three species of them have a basal swelling on the free segment of female leg 5 , as the new species. They are $D$. claudus associated with Ophiuroidea from Indonesia, $D$. inaequalis associated with Zoantharia from Madagascar, and D. sensilis associated with Nudibranchia from Madagascar. Doridicola portincola n. sp. is dissimilar to $D$. claudus and $D$. inaequalis in many respects. In the latter two species the body is small (less than $1 \mathrm{~mm}$ in length in the female), the genital double-somite is longer than wide, the caudal ramus is distinctly longer than wide (the ratio of length to width being $3.46: 1$ in $D$. claudus and $1.79: 1$ in D. inaequalis, according to Humes and Stock, 1973 and Humes and Ho, 1966, respectively), the third segment of antenna bears 3 setae (without claw), the two setae on the second segment of female maxilliped are similar in size, and the free segment of female leg 5 is not more than 2.5 times as long as wide. 
Unlike the great differences of $D$. portinocla $\mathrm{n}$. $\mathrm{sp}$. from both $D$. claudus and $D$. inaequalis, its difference from $D$. sensilis is very slight. Differences between $D$. portincola $\mathrm{n}$. sp. and $D$. sensilis are present in the female maxilliped, leg 4 and caudal ramus. In the female maxilliped one of the two setae on the second segment is about four times as long as the other in $D$. portincola $\mathrm{n}$. sp. but about twice as long as the other in D. sensilis according to the figure in the original description by Humes (1964). The two terminal spines on the distal endopodal segment of leg 4 are subequal in size in D. portincola $\mathrm{n}$. sp. $(43$ and $33 \mu \mathrm{m})$ but distinctly unequal in D. sensilis ( 72 and $43 \mu \mathrm{m}$ ). Finally, the caudal ramus in the female is slightly shorter than wide in $D$. portincola $\mathrm{n}$. sp. but longer than wide (ratio $1.30: 1$ ) in $D$. sensilis.

As the notable points, both species are associated with the Nudibranchia and carry in common the peculiarly shaped seta on the first and second segment of male antenna as shown in Fig. 192 of Humes (1964) and Fig. 6C in the present paper. The seta, which is expanded proximally and armed with minute spinules along inner margin, is interestingly observable also in some other species of Doridicola associated with Nudibranchia or Cephalopoda, as in $D$. patulus (Humes, 1959) and D. venustus (Humes, 1959) both associated with Nudibranchia, and D. similis (Ho and Kim, 2001) associated with Cephalopoda. This fact may support the suggestion of Ho and Kim (2001) that the modern species of Doridicola associated with cephalopods were originated from an ancestor associated with nudibranch mollusks.

\section{REFERENCES}

Boxshall, G.A. and S.H. Halsey, 2004. An Introduction to Cope- pod Diversity, Part II. The Ray Society, London, pp. 422966.

Ho, J.-S., 1983. Metaxymolgus longicauda (Claus), a copepod associated with the cuttlefish, Sepia officinalis L. J. Mar. Biol. Ass. U.K., 63: 199-203.

Ho, J.-S. and I.-H. Kim, 2001. New species of Doridicola (Copepoda, Rhynchomolgidae) from Thailand, with a cladistic analysis of the genus. J. Crustacean Biol., 21(1): 7889.

Humes, A.G., 1964. New species of Lichomolgus (Copepoda, Cyclopoida) from sea anemones and nudibranchs in Madagascar. Cah. ORSTOM, Océanogr., 6 (Série Nosy Bé II): 59-130.

Humes, A.G. and G.A. Boxshall, 1996. A revision of the lichomolgoid complex (Copepoda: Poecilostomatoida), with the recognition of six new families. J. Nat. Hist., 30: 175-227.

Humes, A.G. and M. Dojiri, 1979. Poecilostome copepods (Lichomolgidae) associated with the alcyonacean Litophyton in the Moluccas. Trans. Amer. Microsc. Soc., 98(3): 337-352.

Humes, A.G. and J.-S. Ho, 1968. Cyclopoid copepods of the genus Lichomolgus associated with octocorals of the family Nephtheidae in Madagascar. Proc. U.S. Nat. Mus., 125: 141.

Kim, I.-H., 1998. Illustrated Encyclopedia of Fauna and Flora of Korea. Vol. 38. Cirripedia, Symbiotic Copepoda, and Pycnogonida. Ministry of Education, Korea, p. 1038. (in Korean)

Kim, I.-H., 2003. Copepods (Crustacea) associated with marine invertebrates from New Caledonia. Korean J. Syst. Zool., Special Issue, 4: 1-167.

Kim, I.-H., 2004. Copepods (Crustacea) associated with marine invertebrates from Great Barrier Reef, Australia. Korean J. Syst. Zool., 20(2): 109-140.

Received September 3, 2007 Accepted October 26, 2007 